\title{
Diuretic and antioxidant activities of the aqueous extract of leaves of Vepris heterophylla (Engl.) R. Let (Rutaceae) in rats
}

Fidèle Ntchapda ${ }^{1 *}$, Christian Bonabe ${ }^{1}$, David Romain Kemeta Azambou', Emmanuel Talla² and Théophile Dimo ${ }^{3}$

\begin{abstract}
Background: Vepris heterophylla (Rutaceae) is a medicinal plant used empirically in African traditional medicine for many clinical conditions including edematous disorders and hypertension. $V$. heterophylla aqueous extract has been used in northern part of Cameroon by traditional healers for the treatment of arterial hypertension. The study aim was to assess the putative diuretic and antioxidant properties of $V$. heterophylla leaves aqueous extract.

Methods: Adult rats were administered with V. heterophylla leaves aqueous extract acutely (24 h) at doses 50, 100, 150, 200 and $250 \mathrm{mg} / \mathrm{kg}$ (per os). The two positive control groups received the diuretic drugs furosemide $(5 \mathrm{mg} / \mathrm{kg}$ ) and hydrochlorothiazide (HCTZ, $10 \mathrm{mg} / \mathrm{kg}$ ), while negative control group received only an equivalent volume of distilled water. Urinary elimination of electrolytes in response to treatments was evaluated, together with changes in concentrations of creatinine, urea, aldosterone, glucose and albumin in urine and plasma. Various urinary indicators of kidney function and plasmatic markers of oxidative stress were also assessed.

Results: The findings indicated that the aqueous extract of $V$. heterophylla at doses ranging from 150 to $250 \mathrm{mg} / \mathrm{kg}$ caused a significant and dose-dependent increase of urinary water and electrolytes excretion in normal rats. The aqueous extract of the leaves of $V$. heterophylla accelerated the elimination of overloaded fluid. At the maximum of diuretic response, urinary osmolarity decreased significantly when compared with controls. Oral administration of aqueous extract at different doses produced a significant diuresis and slight increase in electrolytes $\left(\mathrm{Na}^{+}, \mathrm{K}^{+}\right.$and $\left.\mathrm{Cl}^{-}\right)$ excretion. The results obtained were compared with standard drug-furosemide $(5 \mathrm{mg} / \mathrm{kg})$ and hydrochlorothiazide $(10 \mathrm{mg} / \mathrm{kg}$ ). These effects were observed predominantly at $250 \mathrm{mg} / \mathrm{kg}$ dose.
\end{abstract}

Conclusions: Our findings strongly suggest that $V$. heterophylla aqueous extract has diuretic and antioxidant activities, and deserves further studies considering the potential for the treatment of hypertension.

Keywords: Vepris heterophylla, Diuretic, Antioxidant, Urine, kidney function, Electrolytes

\section{Background}

Arterial hypertension is among the most frequent pathologies in elderly worldwide, with an incidence ranging from $40 \%$ (about 65 years patients) to $90 \%$ (patients older than 85) in developed countries [1,2]. This pathology raises more concerns as it constitutes a major risk of cardiovascular accident. In many of the developing countries, the use of plant drugs against arterial hypertension is increasing because modern life saving drugs

\footnotetext{
*Correspondence: ntchapda71@yahoo.fr

'Department of Biological Sciences, Faculty of Sciences, University of

Ngaoundéré, P.O. Box 454, Ngaoundéré, Cameroon

Full list of author information is available at the end of the article
}

are beyond the reach of their countries although they spend $40-50 \%$ of their total wealth on drugs and healthcare [3]. Many investigators demonstrated that studies of herbal plant used in traditional medicine as diuretics were in progressive elevation in the last decades, and might be a precious tool used in human pathology treatment [4]. In Cameroon, different types of complementary and alternative treatments are believed to be effective for treating high blood pressure. Using a diuretic to prevent cardiovascular complications plays an important role in the management of arterial hypertension [5]. These diuretics increase the drainage of water and salt (sodium) into the urine, causing a reduction of 
blood pressure, a decrease in blood volume, and thus lowering resistance to the flow of blood [6]. Efforts of Cameroonians scientists and traditional therapists are growing in the direction of improvement and enhancement of the use of medicinal plants, to elucidate the pharmacological properties of these plants and possibly to extract active ingredients. The medicinal value of these plants lies in some chemical active substances that produce a definite physiological action on the human body. The most important of these chemically active (bioactive) constituents of plants are: saponin, glycosides and flavonoid compounds. Many of these indigenous medicinal plants are also used for medicinal purposes [7].

Vepris heterophylla is a medicinal plant used empirically in the mountainous massifs in the northern part of Cameroon for the treatment of various illnesses such as malaria and cardio-vascular disorders [8]. The vernacular names of this species are Kounikoutchoum (Guiziga, Mofou), Hohoum (Zoulgo), Gougouvetche (Mafa), Kotokolhi (fulfulde) which testifies its importance in this region [9]. The medicinal virtues of this Rutaceae on high blood pressure have already been pointed out by several authors: $[10,11]$. The efficacy of $V$. heterophylla leaf extract in bringing relieve to patients with cardiovascular diseases was previously demonstrated. The vascular effects of $V$. heterophylla methanol leaf extract in experimental rat thoracic aortic strips, with a view of providing a pharmacological justification (or otherwise) to the ethno-medical uses of the plant leaf in the management, control and/or treatment of hypertension and certain cardiac dysfunctions was demonstrated [12]. This study indicated that, the vasorelaxation induced by the methanol leaf extract plant was endothelium dependent effect, likely via the NO-cGMP pathway or independent associated mediators such as prostacyclin [13]. A flavonoid (6,8-dihydroxy-4' - methoxyflavone) isolated from stem bark was found to induced nitric oxide-dependent vasodilation in rat aorta [14]. In the same order a triterpen $(3 \beta-16 \beta, 23$, 29-tetrahydroxyoleane-12-ene) isolated from stem bark was found to increase intracellular $\mathrm{Ca}^{2+}$ in rat aorta endothelial cells [15]. To our knowledge, there have been no reports on the diuretic and antioxidant activities of $V$. heterophylla leaves. The present work aim was to measure the diuretic and antioxidant activities of the aqueous extract of $V$. heterophylla leaves in rats.

\section{Methods}

\section{Animals and procedures}

Wistar rats $(168.8 \pm 2.7 \mathrm{~g})$ of both sexes obtained from Yaoundé's Pasteur Institute (Cameroon) were reared in the Department of Biological Sciences, Faculty of Sciences (University of Ngaoundéré, Cameroon). Animals were housed under controlled temperature $\left(24 \pm 2{ }^{\circ} \mathrm{C}\right)$ and relative humidity ( $45 \pm 10 \%$ ), and had ad libitum access to food [pellets from Cameroonian National Veterinary laboratory (LANAVET)] and tap water. Animal health status and housing conditions were monitored by a veterinary physician. Preliminary tests were performed as previously described [16]. Briefly, rats received distilled water per os $(10 \mathrm{~mL} / \mathrm{kg}$ body weight), and placed individually in metabolic cages. After $6 \mathrm{~h}$, urine was collected and the volume measured. Animals excreting at least $40 \%$ of the volume of distilled water received were selected for the study, and conversely, those excreting less than $40 \%$ were excluded. Then, selected animals were placed individually in metabolic cages, and allowed 7 days for acclimation. Eight experimental groups were obtained by treating $n=5$ rats (per group) with a specific solution, i.e.: vehicle solution (distilled water, per os) for the negative control group, one of the 5 different doses of extract investigated for the 5 test groups (per os), and the diuretic drugs furosemide $(5 \mathrm{mg} / \mathrm{kg}$ ) or hydrochlorothiazide (HCTZ) $(10 \mathrm{mg} / \mathrm{kg}$ ) for the positive control groups. Animals were sacrificed by decapitation at the end of the experiment. Arteriovenous blood was collected in heparinized tubes and centrifuged (3000 rev/min for $10 \mathrm{~min}$ ). The plasma collected was stored at $-20^{\circ} \mathrm{C}$ for biochemical analyses. The liver and kidneys were dissected out, cleaned of fat material, weighed and stored at $-20{ }^{\circ} \mathrm{C}$ for biochemical analyses. Urine was collected and the volume determined each hour from the treatment for 6 h (i.e. 1, 2, 3, 4, 5 and $6 \mathrm{~h}$ after treatment) and $24 \mathrm{~h}$ after in all experimental groups. Electrolyte concentrations $\left(\mathrm{Na}+, \mathrm{K}+\right.$ and $\left.\mathrm{Cl}^{-}\right)$ were measured in $24 \mathrm{~h}$ urine and in blood plasma obtained from animals sacrificed $24 \mathrm{~h}$ after treatment. Experimental procedures were approved by the institutional Animal Care and Use Committee and the research was approved by the Ethics Committee of the Department of Biological Science of the University of Ngaoundéré (ECDBSUN 15/01/2015/UN/FS/DSB).

\section{Concentrations of other blood molecules}

A two-way digital spectrophotometer (Secomam RS232C, Secomam SAS, France) was used to determine the concentrations of urea, glucose, albumin and creatinine in plasma and urine samples. Similarly malondialdehyde concentration was determined in plasma, and catalase, Glutathion, hydroperoxide and protein concentrations were determined in hemolysates of blood pellets and in liver homogenates. Aldosterone concentration in the plasma was measured using radioimmunoassay (assay kit Aldo RIACT, ALPCO Diagnostics, USA).

\section{Plant extract preparation \\ Plant material collection}

Vepris heterophylla leaves were harvested in August 2013 in Kaliyao locality of Mokolo (Far North Region, 
Cameroon) $\left(10^{\circ} 39.214{ }^{\prime} \mathrm{N}, 14^{\circ} 24.145^{\prime} \mathrm{E}, 375 \mathrm{~m}\right.$ asl $)$. The identification and authentication were done in the National Herbarium of Cameroon where a voucher specimen was kept under the No 61615/HNC.

\section{Aqueous extract leaves processing}

Fresh leaves of $V$. heterophylla were soaked in distilled water (1000 g for $1 \mathrm{~L}$ at room temperature) for $12 \mathrm{~h}$. The mixture was shaken vigorously for $10-15 \mathrm{~s}$ and allowed to stand for about $30 \mathrm{~min}$ and then filtered through a $150 \mu \mathrm{m}$ aperture sieve to obtain the macerate. The macerate was filtered through Whatman filter paper $\mathrm{N}^{\mathrm{o}} 3$, and the aqueous extract was there after lyophilized to give a yield of $10.26 \%$. The sample was then placed in air-tight containers and refrigerated at $-20{ }^{\circ} \mathrm{C}$ until use.

\section{Aqueous extract doses}

The doses were given starting from the dose of the traditional expert. The solution of $V$. heterophylla extract with the highest concentration tested was prepared by dissolving $500 \mathrm{mg}$ of the concentrated crude extract obtained previously in $10 \mathrm{ml}$ of distilled water $(50 \mathrm{mg} / \mathrm{mL}$ concentration). The other solutions used in the study were 4:5, 3:5, 2:5 and 1:5 dilutions of this solution in distilled water. Solutions were given per os in a volume of $5 \mathrm{ml} / \mathrm{kg}$ body weight, thus, the increasing doses of aqueous extract of $V$. heterophylla tested were 50, 100, 150, 200 and $250 \mathrm{mg} / \mathrm{kg}$.

\section{Determination of urinary and/or plasma concentrations}

Osmolar clearance (Cosm) was calculated using plasma osmolality (POSM), urinary osmolarity (Uosm) and urine flow $(\mathrm{V})$ according to the following formula: Cosm $=$ Uosm $\times$ V/POSM. Urinary and plasma concentrations of $\mathrm{Na}^{+}, \mathrm{K}^{+}$and $\mathrm{Cl}^{-}$ions were evaluated using flame photometry (Jenway PFP 7, Bibby Scientific, USA), following standard protocols. Osmolarity of plasma and urine samples were measured by cytometry using an osmometer (Knauer). Urinary natriuresis was measured during the diuretic response, particularly at the maximum excretion rate. Doses of $\mathrm{Na}^{+}$and $\mathrm{K}^{+}$were calculated as indicators of saluretic activity and the ratio $\mathrm{Na}^{+} / \mathrm{K}^{+}$was calculated for the natriuretic activity. And to estimate the carbonic anhydrase inhibition activity, the ratio of $\mathrm{Cl}^{-}$ions to $\mathrm{Na}^{+}$and $\mathrm{K}^{+}$ions was calculated [17]. A two-way digital spectrophotometer (Secomam RS232C, Secomam SAS, France) was used to determine the concentrations of urea, glucose, albumin and creatinine in plasma and urine samples. Similarly malondialdehyde concentration was determined in plasma, and catalase, hydroperoxide and protein concentrations were determined in hemolysates of blood pellets and in liver homogenates. Aldosterone concentration in the plasma was measured using radioimmunoassay (assay kit Aldo RIACT, ALPCO Diagnostics, USA).

\section{Phytochemical studies}

In order to identify the chemical structure of the compounds responsible for the diuretic activity, preliminary tests of the phytochemical study were conducted following the procedures described by Trease and Evans [18]. Briefly, Essential oils from the aqueous extract of $V$. heterophylla were extracted with hexane. These extracts were then stitched onto plates of thin layer chromatography on silica, the first disclosure was obtained by ultraviolet radiation $(254 \mathrm{~nm}$ and $365 \mathrm{~nm}$ ) and then with vanillin. Analytical tests for the identification of different families of metabolites in crude extracts of the leaves were performed at the national Institute of Medicinal Plants for Medicinal research (IMPM, Cameroon).

\section{Statistical analyses}

Data from test groups and positive control groups were compared to negative control group using one-way ANOVA followed by LSD test for post hoc analysis, using Origin software (OriginLab, Northampton, MA, USA). Changes with $P$ values lower than 0.05 were considered significant. Data are presented as mean \pm SEM.

\section{Results}

\section{Phytochemical study}

Phytochemical screening performed on crude extracts revealed the presence of several primary and secondary metabolites such as fatty acids, Athraquinones, volatile oils, glycosides, saponins, tannins, coumarins and triterpenes. Phenolic compounds and sterols were also present in the extract. The presence of flavonoids and alkaloids was significant. The various phytochemical compounds detected are known to have beneficial importance in industrial and medicinal sciences. These initial results suggest that the aqueous extract of leaves of $V$. heterophylla contains several chemical compounds whose potential biological activity remains to be demonstrated.

\section{Overload eliminated after $1 \mathrm{~h}$ and latency to first urination}

All treatments induced at least a 3 -fold increase in the overload elimination compared with negative control group after 60s. Only $30.54 \%$ overload was eliminated in the negative control group, whereas HCTZ eliminated $85.34 \%$ and furosemide $90.66 \%(P<0.001)$. The response of the extract was dose-dependent, and eliminated $80.62 \%$ of overload at $150 \mathrm{mg} / \mathrm{kg} \quad(P<0.001$ against negative control group), $92.44 \%$ at $200 \mathrm{mg} / \mathrm{kg}$ $(P<0.01)$ and $127.38 \%$ at $250 \mathrm{mg} / \mathrm{kg}(P<0.001)$ (Fig. 1$)$. The overload eliminated after $1 \mathrm{~h}$ by rats treated with the three highest doses of extract (150, 200 and $250 \mathrm{mg} /$ $\mathrm{kg}$ ) were respectively $26.23 ; 52.88$ and $70.87 \%$, whereas 


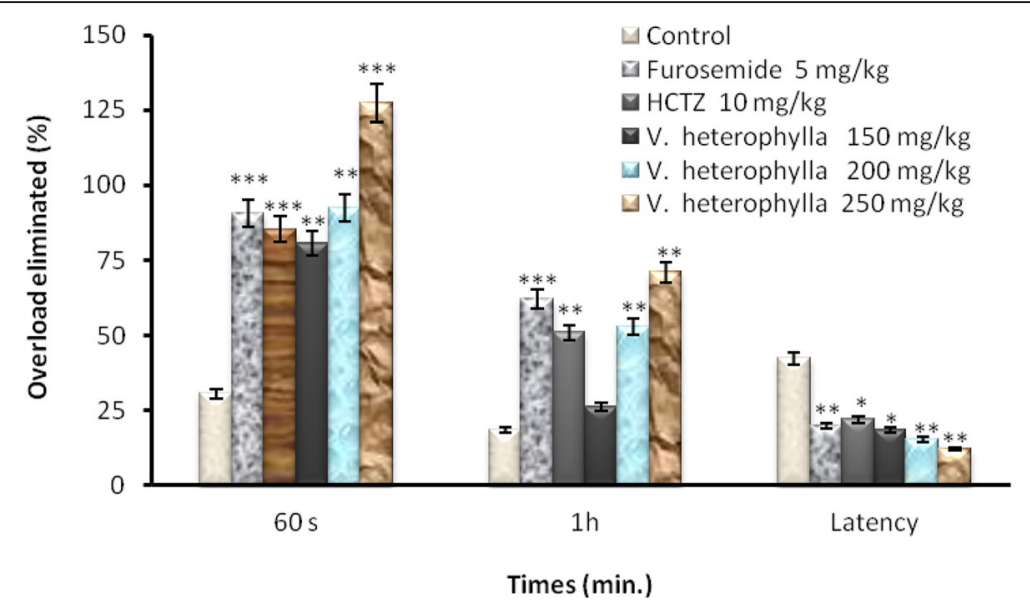

Fig. 1 Overload eliminated and urination latency. Overload eliminated after $1 \mathrm{~h}$ and latency to first urination by rats treated with the three highest doses of $V$. heterophylla aqueous extract tested, administered with an equivalent volume of distilled water (negative controls), or rats treated with one of the two diuretic drugs used as positive controls. Note that all treatments induced at least a 3-fold increase in the overload elimination compared with negative controls. ANOVA + LSD test against negative control group: ${ }^{*} P<0.05,{ }^{* *} P<0.01,{ }^{* * *} P<0.001$

HCTZ eliminated $51.04 \%$ furosemide $61.87 \%$ and control $18.31 \%(P<0.001)$ (Fig. 1). The extract displayed a dose-dependent decrease as the first urination latency with $18.38 \mathrm{~min}(P<0.05)$, $15.24 \mathrm{~min}(P<0.01)$, and $12.11 \mathrm{~min}(P<0.01)$ at doses 150,200 and $250 \mathrm{mg} / \mathrm{kg}$. Negative control group average first urination latency was $42.34 \mathrm{~min}$, furosemide $19.66 \mathrm{~min}(P<0.01)$, and HCTZ $21.87 \min (P<0.05)$ (Fig. 1).

\section{Urinary volume and electrolyte excretion}

Table 1 shows the changes in the total volume of urine excreted by rats after $24 \mathrm{~h}$ following treatment with various doses of $V$. heterophylla aqueous extract, administration of an equivalent volume of distilled water (negative controls), or treatment with one of the two diuretic drugs used as positive controls (furosemide, HCTZ). The doses $50 \mathrm{mg} / \mathrm{kg}$ and $100 \mathrm{mg} / \mathrm{kg}$ were not significant (data not shown). The volume of urine went from $231.31 \pm 2.38 \mathrm{ml} / \mathrm{kg} / 24 \mathrm{~h}$ in control group to $393.04 \pm 3.62 \mathrm{ml} / \mathrm{kg} / 24 \mathrm{~h}$ in the group treated with the highest dose. A single dose-response administration of the aqueous extract of $V$. heterophylla (150, 200 and
$250 \mathrm{mg} / \mathrm{kg})$ significant increased $(P<0.05)$ the volume of urine $24 \mathrm{~h}$ later. However, the urinary excretion was dose dependant (Table 1). The volume of urine of $208.22 \pm 2.43 \mathrm{ml} / \mathrm{kg} / 24 \mathrm{~h}$ in controls (distilled $\mathrm{H}_{2} \mathrm{O}$ ) significantly increased to $254.11 \pm 3.23 \mathrm{ml} / \mathrm{kg} / 24 \mathrm{~h}$ $(22.11 \%$ increment) at the dose of $150 \mathrm{mg} / \mathrm{kg}$. At the dose of $200 \mathrm{mg} / \mathrm{kg}$, the volume of urine increased by $37.50 \%$. The highest dose $(250 \mathrm{mg} / \mathrm{kg})$, induced $72.11 \%$ increase of the treated group. All treatments increased the urinary excretion of $\mathrm{Na}^{+} ; \mathrm{Cl}^{-}$and $\mathrm{k}^{+}$compared to negative control group; the extract response was dosedependent (Table 1).

After $24 \mathrm{~h}$, the extract significantly $(P<0.001)$ increased the urinary excretion of $\mathrm{Na}^{+}$and $\mathrm{Cl}^{-}$from $23.32 \pm$ $1.11 \mathrm{mEq} / \mathrm{kg}$ and $19.33 \pm 1.41 \mathrm{mEq} / \mathrm{kg}$ (negative control group), respectively, to $59.22 \pm 2.23 \mathrm{mEq} / \mathrm{kg}$ and $53.16 \pm$ $1.32 \mathrm{mEq} / \mathrm{kg}(150 \mathrm{mg} / \mathrm{kg}), 112.33 \pm 1.33 \mathrm{mEq} / \mathrm{kg}$ and $107.33 \pm 1.41 \mathrm{mEq} / \mathrm{kg}(200 \mathrm{mg} / \mathrm{kg})$, and $166.28 \pm$ $1.22 \mathrm{mEq} / \mathrm{kg}$ and $158.67 \pm 1.42 \mathrm{mEq} / \mathrm{kg}(250 \mathrm{mg} / \mathrm{kg})$. The urinary excretion of $\mathrm{Na}^{+}$and $\mathrm{Cl}^{-}$induced by furosemide were $101.66 \pm 2.11 \mathrm{mEq} / \mathrm{kg}$ and $99.77 \pm 2.22 \mathrm{mEq} / \mathrm{kg}$ $(P<0.001)$, respectively and HCTZ $81.77 \pm 1.31 \mathrm{mEq} /$

Table 1 Effects of the aqueous extract of $V$. heterophylla on the urinary volume and excretion of $\mathrm{Na}^{+}, \mathrm{Cl}^{-}$and $\mathrm{K}^{+}$

\begin{tabular}{|c|c|c|c|c|c|}
\hline \multicolumn{6}{|c|}{ Urinary volume and excretion of $\mathrm{Na}^{+}, \mathrm{Cl}-$ and $\mathrm{K}^{+}$} \\
\hline \multicolumn{2}{|c|}{ Drugs (mg/kg) } & Urinary volume (mL/kg/24 h) & $\mathrm{Na}^{+}(\mathrm{mEq} / \mathrm{kg} / 24 \mathrm{~h})$ & $\mathrm{Cl}^{-}(\mathrm{mEq} / \mathrm{kg} / 24 \mathrm{~h})$ & $\mathrm{K}^{+}(\mathrm{mEq} / \mathrm{kg} / 24 \mathrm{~h})$ \\
\hline \multicolumn{2}{|l|}{ Control } & $208.22 \pm 2.43$ & $23.32 \pm 1.11$ & $19.33 \pm 1.41$ & $23.11 \pm 0.66$ \\
\hline \multirow[t]{3}{*}{ Extract } & 150 & $254.11 \pm 3.23^{* * *}$ & $59.22 \pm 2.23^{* * *}$ & $53.16 \pm 1.32^{* * *}$ & $44.18 \pm 1.31^{* * *}$ \\
\hline & 200 & $286.13 \pm 2.13^{* * *}$ & $112.33 \pm 1.33^{* * *}$ & $107.33 \pm 1.41^{* * *}$ & $60.34 \pm 1.22^{* * *}$ \\
\hline & 250 & $358.08 \pm 3.13^{* * *}$ & $166.28 \pm 1.22^{* * *}$ & $158.67 \pm 1.42^{* * *}$ & $52.33 \pm 2.14^{* * *}$ \\
\hline \multicolumn{2}{|c|}{ Furosémide (5 mg/kg) } & $398.12 \pm 1.77^{* * *}$ & $101.66 \pm 2.11^{* * *}$ & $99.77 \pm 2.22^{* * *}$ & $40.77 \pm 2.22^{* * *}$ \\
\hline \multicolumn{2}{|c|}{ Amiloride H. (10 mg/kg) } & $237.11 \pm 4.33^{* *}$ & $81.77 \pm 1.31^{* * *}$ & $77.22 \pm 2.11^{* * *}$ & $29.66 \pm 1.13^{* *}$ \\
\hline
\end{tabular}

Values are means \pm S.E.M., $n=5,{ }^{* *}<0.01,{ }^{* * *}<0.001$, significant difference compared to the control 
$\mathrm{kg}$ and $77.22 \pm 2.11 \mathrm{mEq} / \mathrm{kg}(P<0.001)$ (Table 1$)$. The urinary excretion of $\mathrm{K}^{+}$induced by extract at the dose of $250 \mathrm{mg} / \mathrm{kg}$ were $52.33 \pm 2.14 \mathrm{mEq} / \mathrm{kg}$ and furosemide $40.77 \pm 2.22 \mathrm{mEq} / \mathrm{kg}(P<0.001)$, HCTZ $29.66 \pm$ $1.13 \mathrm{mEq} / \mathrm{kg}(P<0.001)$ (Table 1$)$.

All experimental groups had a significantly higher slope $(P>0.01)$ than the negative control group $(y=$ $\left.0.15 \mathrm{x}+16.9, \quad \mathrm{R}^{2}=0.59\right)$, furosemide $(y=11.5 \mathrm{x}+85.9$, $\left.\mathrm{R}^{2}=0.99\right), \quad$ HCTZ $\left(y=10.4 \mathrm{x}+60.9, \quad \mathrm{R}^{2}=0.98\right), \quad$ and extract-treated groups $\left(y=13.1 \mathrm{x}+165.6, \quad \mathrm{R}^{2}=0.98\right)$. The effects of treatment with extract or diuretic drugs on $\mathrm{K}^{+}$amount excreted was also more marked with time: extract-treated groups $\left(y=5.7 \mathrm{x}+23.9, \mathrm{R}^{2}=0.99\right)$, furosemide $\left(y=3.6 \mathrm{x}+13.2, \mathrm{R}^{2}=0.98\right)$ and $\operatorname{HCTZ}(y=$ $\left.4.5 \mathrm{x}+10.1, \mathrm{R}^{2}=0.97\right)$.

\section{Urine output index and $\mathrm{pH}$}

The urinary $\mathrm{pH}$ in negative control group was slightly decreased in groups treated with furosemide $(6.68 \pm 0.1)$ or HCTZ $(6.54 \pm 0.1)$, and slightly increased in groups receiving the extract (7.6), with the doses (150, 200 and $250 \mathrm{mg} / \mathrm{kg}$ ). However, these changes were not statistically significant compared to the control (Fig. 2). Diuretic index of the plant extract is lower than that of furosemide (1.91) and higher than that of HCTZ (1.13) at the dose $150 \mathrm{mg} / \mathrm{kg}$ (1.22), $200 \mathrm{mg} / \mathrm{kg}$ (1.37) and $250 \mathrm{mg} / \mathrm{kg}$ (1.72) (Table 2). At the dose of $150 \mathrm{mg} / \mathrm{kg}, V$. heterophylla showed a significantly $(p<0.05)$ high urinary $\mathrm{pH}$ when compared to the control group (Fig. 2). The $\mathrm{pH}$ values $(7.6 \pm 0.1)$ of urine treated with the extract of $V$. heterophylla were higher than the control group (7.1 \pm 0.2$)$. Doses of 150 and $200 \mathrm{mg} / \mathrm{kg}$ showed a significantly increased $\mathrm{pH}$ values. However, the $\mathrm{pH}$ value $(7.6 \pm 0.1)$ of urine of animals treated with pharmacological substances were lower than that of rats treated with extract at the doses of 150; 200 and $250 \mathrm{mg} / \mathrm{kg}$ (7.6 \pm 0.1$)$ (Fig. 2).

\section{Saluretic and natriuretic activities}

Saluretic and natriuretic activities were significantly increased by diuretic drugs $(P<0.001)$ and by the extract $(P<0.001)$ at the highest dose tested (Table 3$)$. Similarly, carbonic anhydrase inhibition was also increased by diuretic drugs $(P<0.01)$ and by the extract $(P<0.01$ at the highest dose tested). On the same hand, carbonic anhydrase inhibition, saluretic, natriuretic, diuretic, as well as $\mathrm{Na}^{+}$and $\mathrm{Cl}^{-}$indexes were high for in all groups, but the extract effect at $250 \mathrm{mg} / \mathrm{kg}$ (higher dose used) was 2fold higher than the diuretic drugs at the dose used (Table 3). Notably, K+ index was only slightly increased by the diuretic drugs and the extract (Table 2).

\section{Urinary indexes of kidney function}

Treatments with the various doses of extract and the diuretic drugs decreased the GFR from $1.74 \pm 0.12 \mathrm{~mL} /$ $\mathrm{min}$ in the negative control group to $1.56 \pm 0.16 \mathrm{~mL} /$ min, (extract at $250 \mathrm{mg} / \mathrm{kg}, \quad P<0.01$ ) and $1.49 \pm$ $0.22 \mathrm{~mL} / \mathrm{min}$ (furosemide, $P<0.001$ ), $1.46 \pm 0.32 \mathrm{~mL} /$ min (HCTZ, $P<0.001)$. The analysis of the collected urine of rats $24 \mathrm{~h}$ after administration of a single dose of the extract of $V$. heterophylla revealed no trace of glucose and albumin. The effect of $V$. heterophylla aqueous extract and diuretic drug treatment (compared to negative control group) on indexes of kidney function in urine produced in the $24 \mathrm{~h}$ following the treatment are shown in Table 4. The aqueous extract of $V$. heterophylla caused no significant change in rate of urinary creatinine (Table 4). Urea concentration in the urine was significant $(p<0.05)$ decreased by $8.33 \%$ at dose $250 \mathrm{mg} / \mathrm{kg}$ (Table 4). Osmotic clearance significantly increased by $45.65 \%$ at the highest dose of extract. The creatinine

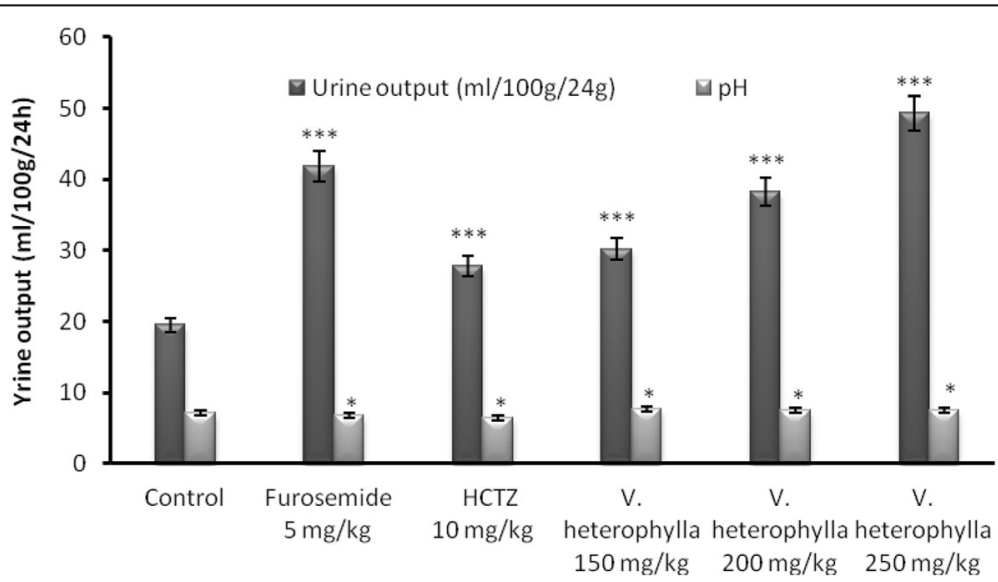

Fig. 2 Effects of the aqueous extract of $V$. heterophylla on the urine output and pH. Values are means \pm S.E.M., $n=5,{ }^{*}<0,05,{ }^{* * *}<0,001$, significant difference compared to the control 
Table 2 Effects of the aqueous extract of $V$. heterophylla on urine output index and electrolytic excretion index in $24 \mathrm{~h}$ of urine collection

\begin{tabular}{|c|c|c|c|c|c|c|}
\hline \multicolumn{2}{|c|}{ Drugs (mg/kg) } & \multirow{2}{*}{$\begin{array}{l}\text { Diuretic index } \\
1.00\end{array}$} & \multirow{2}{*}{$\begin{array}{l}\mathrm{Na}^{+} \text {index } \\
1.00\end{array}$} & \multirow{2}{*}{$\begin{array}{l}\mathrm{Cl}^{-} \text {index } \\
1.00\end{array}$} & \multirow{2}{*}{$\frac{\mathrm{K}^{+} \text {index }}{1.00}$} & \\
\hline Control & & & & & & \\
\hline \multirow[t]{3}{*}{ Extract } & 150 & 1.22 & 2.56 & 2.78 & 1.91 & \\
\hline & 200 & 1.37 & 4.86 & 5.63 & 2.60 & \\
\hline & 250 & 1.72 & 7.21 & 8.31 & 2.26 & \\
\hline \multicolumn{2}{|c|}{ Furosémide ( 5 mg/kg) } & 1.91 & 5.22 & 5.21 & 1.73 & \\
\hline \multicolumn{2}{|c|}{ Amiloride H. (10 mg/kg) } & 1.13 & 4.39 & 4.05 & 1.26 & \\
\hline
\end{tabular}

$n$ number of animals used in each group

diuretic index: urine volume of test group/urine volume of control group

$\mathrm{Na}^{+}$index, sodium excretion in test group/sodium excretion in control group

$\mathrm{K}^{-}$index, potassium excretion in test group/potassium excretion in control group

clearance also decreased $35.10 \%$ (Table 4). Osmolar clearance and free water clearance were increased, while urinary osmolarity decreased.

\section{Serum parameters and oxidative stress markers}

Furosemide and HCTZ and the extract at the dose of $250 \mathrm{mg} / \mathrm{kg}$ induced significant increases $(4.49,2.68$ and $5 \%$ respectively, $p<0.05$ ) in albumin level (Table 5 ). Concentrations of $\mathrm{Na}^{+}$and $\mathrm{K}^{+}$ions were significantly increased $(518.18 \%$ and $218.88 \%$ respectively in animals receiving the extract at $250 \mathrm{mg} / \mathrm{kg}, p<0.05$ ) (Table 5). The extract and diuretic drugs induced significant increases $(p<0.05)$ in serum creatinine and urea levels. Increases in plasma osmolality and aldosterone levels were observed $(P<0.001)$ (Table 5$)$. Table 6 showed the effects of the acute administration of $V$. heterophylla aqueous extract at the dose of $250 \mathrm{mg} / \mathrm{kg}$ on markers of oxidative stress. Glutathione concentration in plasma were decreased $(P<0.01)$. The extract also induced a significant decrease in hydroperoxide amount in liver homogenates $(P<0.001)$, and an increase in blood plasma $(P<0.05)$. Catalase activities in liver homogenates and in hemolysates were significantly decreased $(P<0.05)$. Protein amounts were decreased in liver homogenates $(P<0.01)$ and increased in hemolysates $(P<0.05)$. Plasma and liver malondialdehyde amounts were significantly decreased $(p<0.05)$.

\section{Discussion}

Preliminary phytochemical studies showed that aqueous extract of the leaves of $V$. heterophylla contains several chemical compounds that could be partially or fully responsible for the increase of diuresis and moderate natriuretic activity. Saponin is used as a mild detergent and in intracellular histochemistry staining to allow antibody access to intracellular proteins. In medicine, it is used in hypercholesterolaemia, hyperglycaemia, diuresis, antioxidant, anti-cancer, anti-inflammatory and weight loss etc. It is also known to have anti-fugal properties [19]. Tannin are reported to exhibit antiviral, antibacterial, anti-tumor activities. It was also reported that certain tannin are able to inhibit HIV replication selectivity and is also used as diuretic [20]. Cardiac glycosides are known to work by inhibiting the $\mathrm{Na}^{+} / \mathrm{K}^{+}$pump. This causes an increase in the level of sodium ions in the myocytes, which then lead to a rise in the level of calcium ions. This inhibition increases the amount of $\mathrm{Ca}^{2+}$ ions available for contraction of the heart muscle, which improves cardiac output and reduces distention of the heart; thus, they are used in the treatment of congestive heart failure and cardiac arrhythmia. They are also, used to strengthen a weakened heart and allow it to function more efficiently, though the dosage must be controlled carefully, since the therapeutic dose is close to the toxic dose [21]. Plant steroids are known to be important for

Table 3 Effects of the aqueous extract of $V$. heterophylla on saluretic and natriuretic activity from $24 \mathrm{~h}$ of urine

\begin{tabular}{|c|c|c|c|c|c|c|c|}
\hline \multicolumn{2}{|c|}{ Drugs (mg/kg) } & \multirow{2}{*}{$\frac{\text { Saluretic }\left(\mathrm{Na}^{+}+\mathrm{Cl}^{-}\right)}{42.65 \pm 2.52}$} & \multirow{2}{*}{$\frac{\text { Natriuretic }\left(\mathrm{Na}^{+} / \mathrm{k}^{+}\right)}{1.00 \pm 1.68}$} & \multirow{2}{*}{$\frac{\mathrm{CAl} C \mathrm{Cl} /(\mathrm{Na}+\mathrm{K})}{0.45 \pm 0.55}$} & \multirow{2}{*}{$\frac{\text { Saluretic index }}{1.00}$} & \multirow{2}{*}{$\begin{array}{l}\text { Natriuretic index } \\
1.00\end{array}$} & \multirow{2}{*}{$\frac{\text { CAl index }}{1.00}$} \\
\hline Control & & & & & & & \\
\hline \multirow[t]{3}{*}{ Extract } & 150 & $112.38 \pm 3.55^{* * *}$ & $1.34 \pm 1.70^{*}$ & $0.47 \pm 0.37^{*}$ & 2.63 & 1.34 & 1.04 \\
\hline & 200 & $219.66 \pm 2.74^{* * *}$ & $1.86 \pm 1.09^{* *}$ & $0.48 \pm 0.51^{* *}$ & 5.15 & 1.86 & 1.06 \\
\hline & 250 & $324.95 \pm 2.64^{* * *}$ & $3.17 \pm 0.57^{* * *}$ & $0.48 \pm 0.53^{* *}$ & 7.61 & 3.17 & 1.06 \\
\hline \multicolumn{2}{|c|}{ Furosémide (5 mg/kg) } & $201.43 \pm 4.33^{* * *}$ & $2.49 \pm 0.95^{* * *}$ & $0.49 \pm 0.51^{* *}$ & 4.72 & 2.49 & 1.08 \\
\hline \multicolumn{2}{|c|}{ Amiloride H. (10 mg/kg) } & $158.99 \pm 3.42^{* * *}$ & $2.75 \pm 1.15^{* * *}$ & $0.48 \pm 0.61^{* *}$ & 3.72 & 2.75 & 1.06 \\
\hline
\end{tabular}

Values are means \pm S.E.M., $n=5,{ }^{*}<0.05,{ }^{* *}<0.01,{ }^{* *}<0.001$, significant difference compared to the control

$C A l$, carbonic anhydrase inhibition

saluretic index: saluretic activity in test group/saluretic activity in control group

natriuretic index: natriuretic activity in test group/natriuretic activity in control group

carbonic anhydrase inhibition index, CAI activity in test group/CAl activity in control group 
Table 4 Effects of the aqueous extract of $V$. heterophylla on index kidney function

\begin{tabular}{lllllll}
\hline Drugs $(\mathrm{mg} / \mathrm{kg})$ & Control & $150 \mathrm{mg} / \mathrm{kg}$ & $200 \mathrm{mg} / \mathrm{kg}$ & $250 \mathrm{mg} / \mathrm{kg}$ & Furosemide $(5 \mathrm{mg} / \mathrm{kg})$ & $\mathrm{HCTZ}(10 \mathrm{mg} / \mathrm{kg})$ \\
\hline Creatinine $(\mathrm{mg} / 24 \mathrm{~h})$ & $26,66 \pm 1,76$ & $17,77 \pm 1,14^{* * *}$ & $23,45 \pm 1,22^{* *}$ & $27,54 \pm 1,34^{*}$ & $22,33 \pm 1,32^{* *}$ & $28,67 \pm 1,43$ \\
CreatC $(\mathrm{mL} / \mathrm{min})$ & $0,027 \pm 0,33$ & $0,025 \pm 0,14^{*}$ & $0,023 \pm 0,24^{* *}$ & $0,021 \pm 0,11^{* * *}$ & $0,022 \pm 0,31^{* *}$ & $0,020 \pm 0,22^{* * *}$ \\
Urea $(\mathrm{g} / 24 \mathrm{~h})$ & $26,15 \pm 1,16$ & $22,25 \pm 1,01^{* * *}$ & $23,14 \pm 1,23^{*}$ & $24,45 \pm 1,66$ & $24,76 \pm 1,42^{* *}$ & $22,68 \pm 0,34^{* * *}$ \\
Uosm (mosmol/kg) & $198,45 \pm 8,73$ & $109,11 \pm 12,98^{* * *}$ & $112,31 \pm 13,46^{* * *}$ & $125,43 \pm 11,24^{* * *}$ & $169,56 \pm 12,21^{* * *}$ & $166,62 \pm 8,11^{* * *}$ \\
GFR (mL/min) & $1,74 \pm 0,12$ & $1,65 \pm 0,33^{*}$ & $1,62 \pm 0,11^{*}$ & $1,56 \pm 0,16^{* *}$ & $1,49 \pm 0,22^{* * *}$ & $1,46 \pm 0,32^{* * *}$ \\
Cosm (mL/min) & $0,046 \pm 0,013$ & $0,044 \pm 0,021$ & $0,047 \pm 0,032$ & $0,049 \pm 0,043^{* *}$ & $0,078 \pm 0,046^{* * *}$ & $0,067 \pm 0,044^{* * *}$ \\
CH20. (mL/min) & $0,056 \pm 0,012$ & $0,054 \pm 0,013$ & $0,056 \pm 0,011$ & $0,066 \pm 0,016^{* *}$ & $0,068 \pm 0,015^{* * *}$ & $0,066 \pm 0,018^{* * *}$ \\
\hline
\end{tabular}

Values are means \pm S.E.M., $n=5,{ }^{*}<0,05,{ }^{* *}<0,01,{ }^{* * *}<0,001$, significant difference compared to the control

CreatC creatinine clearance, Uosm urinary osmolarity, GFR glomerular filtration rate, Cosm Osmolar clearance, $\mathrm{CH}_{2} \mathrm{O}$ free water clearance

their cardiotonic activities, they possess insecticidal and anti-microbial properties. They are also used innutrition, herbal medicine and cosmetics, they are routinely used in medicine because of their profound biological activities [21]. Flavonoid have been referred to as nature's biological response modifiers because of strong experimental evidence of their inherent ability to modify the body's reaction to allergies, virus and carcinogens. They also show diuresis, anti-allergic, anti-inflammatory, antimicrobial and anti-cancer activity [19].

Findings of the study also indicated that $V$. heterophylla may have antioxidant effects. Comparable observations were reported in a number of other plants with diuretic properties [22]. In addition, the extract also decreased hydroperoxide levels in homogenates, malondialdehyde levels in plasma and the activity of catalase in homogenates and hemolysates, which are markers of oxidative stress [23]. The present study indicated that the aqueous extract of $V$. heterophylla at doses ranging from 150 to $250 \mathrm{mg} / \mathrm{kg}$ caused a significant and dosedependent increase of urinary water and electrolytes excretion in normal rats. It was noted that $V$. heterophylla treatment caused increase in both water and electrolytes excretion qualitatively similar to furosemide which is known by its potential saluretic and diuretic effects [24].
Determination of urinary carbonic anhydrase inhibition revealed that carbonic anhydrase inhibition was not significantly increased. This shows that diuretic activity of aqueous extract of $V$. heterophylla does not make use of carbonic anhydrase inhibition as its mechanism of action [25]. The increase in the ratio of concentration of excreted sodium and potassium ion indicates that the extract increases sodium ion excretion to a greater extent than potassium which is a very essential quality of a good diuretic with lesser hyperkalemia side effect [26].

This study suggest that the aqueous extract leaves of $V$. heterophylla administrated per os had stronger diuretic effects at the doses used in acute studies. The urinary output of rats after oral administration of aqueous extract of $V$. heterophylla showed a statistical difference observed between the test groups given the extract and the control groups during the $1 \mathrm{st} \mathrm{h}$ and after $24 \mathrm{~h}$. There is biological significance in urine volume of positive control in relation to the negative control during the 1 st $\mathrm{h}$ and at the 24th h. Similar observations were reported in studies assessing the other plants with diuretic activity such as Retama raetam [27], and Ficus glumosa [17]. The acute administration of the extract at the dose with the more marked response $(250 \mathrm{mg} / \mathrm{kg})$ induced an increase of $82.58 \%$ in urinary excretion (compared to

Table 5 Effects of the aqueous extract of $V$. heterophylla on the serum parameters

\begin{tabular}{|c|c|c|c|c|c|c|c|c|c|}
\hline \multicolumn{2}{|c|}{$\begin{array}{l}\text { Drugs } \\
\text { (mg/kg) }\end{array}$} & glucose (mg/dl) & Creatinine $(\mathrm{mg} / \mathrm{dl})$ & Urea (mg/dl) & Albumin $(\mathrm{g} / \mathrm{l})$ & Aldosterone (pg/mL) & $\mathrm{Na}^{+}$(méq.L-1) & $\mathrm{K}^{+}$(méq.L-1) & POSM (mosmol/kg) \\
\hline \multicolumn{2}{|l|}{$\overline{\text { Control }}$} & $89,22 \pm 2,11$ & $0,55 \pm 0,22$ & $21,12 \pm 0,38$ & $42,52 \pm 1,14$ & $279,34 \pm 13,41$ & $1,76 \pm 0,43$ & $1,80 \pm 0,77$ & $269,11 \pm 11,11$ \\
\hline \multirow[t]{3}{*}{ Extract } & 150 & $90,45 \pm 2,34^{*}$ & $0,62 \pm 0,45^{*}$ & $22,38 \pm 1,11$ & $43,66 \pm 1,22$ & $281,22 \pm 21,55$ & $6,42 \pm 0,75^{* * *}$ & $3,79 \pm 1,66^{* * *}$ & $277,52 \pm 12,33^{* *}$ \\
\hline & 200 & $91,66 \pm 4,33^{*}$ & $0,66 \pm 0,57^{* *}$ & $23,89 \pm 2,44^{* *}$ & $44,72 \pm 2,34^{* *}$ & $287,57 \pm 12,12^{* *}$ & $8,22 \pm 1,56^{* * *}$ & $4,78 \pm 2,52^{* * *}$ & $279,66 \pm 21,42^{* * *}$ \\
\hline & 250 & $95,88 \pm 3,41^{*}$ & $0,87 \pm 0,29^{* * *}$ & $26,77 \pm 2,33^{* * *}$ & $44,65 \pm 3,67^{* * *}$ & $306,11 \pm 32,22^{* * *}$ & $10,88 \pm 1,56^{* * *}$ & $5,74 \pm 1,16^{* * *}$ & $285,33 \pm 23,43^{* * *}$ \\
\hline \multicolumn{2}{|c|}{$\begin{array}{l}\text { Furosemide } \\
(5 \mathrm{mg} / \mathrm{kg})\end{array}$} & $95,67 \pm 4,98^{*}$ & $0,75 \pm 0,23^{* * *}$ & $24,56 \pm 3,33^{* *}$ & $44,43 \pm 1,63^{* *}$ & $302,53 \pm 23,35^{* * *}$ & $11,22 \pm 1,42^{* * *}$ & $6,73 \pm 1,34^{* * *}$ & $284,21 \pm 24,14^{* * *}$ \\
\hline \multicolumn{2}{|c|}{$\begin{array}{l}\text { HCTZ } \\
(10 \mathrm{mg} / \mathrm{kg})\end{array}$} & $94,22 \pm 3,55^{*}$ & $0,74 \pm 0,61^{* * *}$ & $26,22 \pm 1,13^{* * *}$ & $43,66 \pm 1,32^{* * *}$ & $292,88 \pm 11,23^{* * *}$ & $7,31 \pm 1,72^{* * *}$ & $9,89 \pm 2,51^{* * *}$ & $286,44 \pm 31,56^{* * *}$ \\
\hline
\end{tabular}

Values are means \pm S.E.M., $n=5,{ }^{*}<0,05,{ }^{* *}<0,01,{ }^{* * *}<0,001$, significant difference compared to the control

POSM plasma osmolality 
Table 6 Effects of the aqueous extract of $V$. heterophylla on markers of oxidative stress

\begin{tabular}{|c|c|c|c|c|c|c|c|c|c|}
\hline \multirow[b]{2}{*}{ Treatments } & \multicolumn{4}{|l|}{ Homogenate } & \multicolumn{3}{|l|}{ plasma } & \multicolumn{2}{|l|}{ haemolysates } \\
\hline & $\begin{array}{l}\text { MDA ( } \mu \mathrm{M} \\
100 \mathrm{~g} \text { of tissue) }\end{array}$ & $\begin{array}{l}\mathrm{ROOH}(\mu \mathrm{M} / \\
100 \mathrm{~g} \text { of tissue) }\end{array}$ & $\begin{array}{l}\text { CAT (mMH2O2/ } \\
\text { min/g of protein) }\end{array}$ & $\begin{array}{l}\text { Protein } \\
\text { ( } \mathrm{g} / 100 \mathrm{~g} \text { of tissue) }\end{array}$ & $\begin{array}{l}\text { Glutathion } \\
\text { (mmol/L) }\end{array}$ & $\mathrm{MDA}(\mu \mathrm{M} / \mathrm{l})$ & $\begin{array}{l}\mathrm{ROOH} \\
(\mu \mathrm{M} / \mathrm{l})\end{array}$ & $\begin{array}{l}\text { CAT (mMH2O2/ } \\
\text { min/g of protein) }\end{array}$ & Protein $(\mathrm{g} / \mathrm{l})$ \\
\hline \multirow[t]{2}{*}{$\begin{array}{l}\text { Control } \\
250 \mathrm{mg} / \mathrm{kg}\end{array}$} & $10.45 \pm 1.66$ & $1.66 \pm 0.11$ & $0.03 \pm 0.02$ & $58.11 \pm 0.43$ & $0.45 \pm 0,021$ & $19.77 \pm 1.70$ & $0.03 \pm 0.01$ & $0.01 \pm 0.00$ & $\begin{array}{l}39.79 \pm \\
4.21\end{array}$ \\
\hline & $8.89 \pm 0.77^{*}$ & $0.88 \pm 0.34^{* * *}$ & $0.16 \pm 0.03^{*}$ & $36.67 \pm 3.23^{* *}$ & $0.26 \pm 0,033^{* *}$ & $\begin{array}{l}8.45 \pm \\
2.11^{* * * *}\end{array}$ & $\begin{array}{l}0.05 \pm \\
0.01^{*}\end{array}$ & $0.12 \pm 0.04^{* * *}$ & $\begin{array}{l}49.98 \pm \\
0.34^{*}\end{array}$ \\
\hline
\end{tabular}

Values are means \pm S.E.M., $n=5,{ }^{*} P<0.05,{ }^{*} P<0.01,{ }^{*} P<0.001$, significant difference compared to control rat

$M D A$ malondialdehyde, $R O O H$ 'hydroperoxyde, $C A T$ catalase

negative control group), against $91.20 \%$ and $13.87 \%$ with furosemide and HCTZ, respectively. Diuretics modulate the volume and composition of body fluids in variety of clinical conditions like hypertension. The extract also accelerated the elimination of fluid overload and decreased the latency of the first urination $30.54 \%$ overload was eliminated in the negative control group, whereas HCTZ eliminated $85.34 \%$ and furosemide $90.66 \%$. The response of the extract was dosedependent, and eliminated $80.62 \%$ of overload at $150 \mathrm{mg} / \mathrm{kg}, 92.44 \%$ at $200 \mathrm{mg} / \mathrm{kg}$ and $127.38 \%$ at $250 \mathrm{mg} / \mathrm{kg}$ against negative control group. and the diuretic index of groups treated with the extract was higher $(1.72$ at $250 \mathrm{mg} / \mathrm{kg}$ ) than HCTZ -treated (1.13) but lower than furosemide-treated (1.91). Such rapid diuretic activity may be due to very high concentration of active molecules of the saponin, Cardiac glycosides and flavonoïd families [28], which presence in extracts of $V$. heterophylla was detected by phytochemical analysis in our study and previously reported [13]. The increase natriuresis in response to acute treatment of aqueous extract of leaves of $V$. heterophylla may partly explain the increase in diuresis $[29,30]$. $V$. heterophylla also caused the acidification of urine. There was a significant reduction in the osmolarity of urine in rats treated with the extract. $V$. heterophylla may impair the basal secretion of $\mathrm{ADH}$ and reduce the responsiveness of uriniferous tubules to the action of $\mathrm{ADH}$. Inhibition of $\mathrm{ADH}$ causes polyurea with low osmolarity [31]. Aldosterone hormone measured by radioimmunoassay was slightly increased in animals treated with aqueous extract, and the lack of correlation between plasma aldosterone and sodium concentration in the blood as well as in urine seem to imply that aldosterone is not involved in the natriuresis observed and suggested that stimulation of diuresis by the aqueous extract of the leaves of $V$. heterophylla could be similar to that of furosemide. furosemide increases urinary excretion of sodium by inhibiting $\mathrm{Na}^{+} / \mathrm{K}$ ${ }^{+} / 2 \mathrm{Cl}^{-}$symporter (co-transporter system) in the thick ascending limb of the Henley loop [32], while HCTZ inhibits the $\mathrm{Na}^{+} / \mathrm{Cl}^{-}$symporter (co-transporter system) in the distal convoluted tubule, by competing for the $\mathrm{Cl}^{-}$ binding site, and increasing the excretion of $\mathrm{Na}^{+}$and $\mathrm{Cl}^{-}$
[33]. Whether the extract induces the suppression of renal tubular reabsorption of water and electrolytes by one of these processes or by another mechanism is still to be determined. The increase of the $\mathrm{Na}^{+}$excretion tend to reduced GFR by increasing the $\mathrm{Na}^{+}$load available for $\mathrm{Na}^{+} / \mathrm{K}^{+}$ exchange, stimulating further such exchange by hyperaldosteronism, which causes a reduction in blood volume [34].

Glucose and albumin were not present in treated rats' urine, and no significant change was observed in the urinary creatinine levels. Instead, a marked reduction was observed in the concentration of urea in the urine compared to negative control group, the $\mathrm{K}^{+}$plasmatic concentration was increased, and $\mathrm{Na}^{+}$and $\mathrm{Cl}^{-}$concentrations in the plasma were significantly decreased. Glomerular filtration measured by creatinine clearance does not vary according to treatment compared to controls, which suggest that the increase in diuresis would rather have a tubular origin as seems to show the clearance of free water [16].

Taken together, these results indicate that $V$. heterophylla may act as a loop diuretic which inhibit the $\mathrm{Na}^{+} / \mathrm{K}^{+} / \mathrm{Cl}^{-}$cotransporter system in the thick ascending loop of the nephron, thus increasing natriuresis and kaliuresis.

\section{Conclusion}

In this study, it is evident that the aqueous extract leaves of $V$. heterophylla have potent and dose-response diuretic and antioxidant properties in experimental animal model. In view of all these various uses associated with these compounds found in $V$. heterophylla leaves extract, we recommend further research on this plant leaves to quantify the concentration of these compounds per known amount for industrial use. We believe these compounds in $V$. heterophylla leaves could be harnessed for industrial and medicinal sciences utilization. The present study has also confirmed the ethnopharmacological use of the aqueous extract leaves of $V$. heterophylla as a diuretic agent, but further studies are necessary to evaluate the mechanisms involved in its biological activity and safety following repeated exposure. Furthermore, this work supports the importance of the preservation of local knowledge as well as the conservation of Cameroonian biodiversity 


\section{Abbreviations}

\%: Percentage; CAl: Carbonic anhydrase inhibition; CAT: Catalase; $\mathrm{CH}_{2} \mathrm{O}$ : Free water clearance; Cosm: Osmolar clearance; CreatC: Creatinine clearance; GFR: Glomerular filtration rate; HCTZ: Hydrochlorothiazide; HNC: National Herbarium of Cameroon; LANAVET: National Veterinary Laboratory; MDA: Malondialdehyde; NO-cGMP: Nitric oxide -cyclic guanosine monophosphate; $\mathrm{ROOH}$ : 'Hydroperoxyde; Uosm: Urinary osmolarity; V. heterophylla: Vepris heterophylla

\section{Acknowledgments}

We are profoundly grateful to the University of Yaounde I (Cameroon), the Institute of Medical Research and Medicinal Plants Studies (Cameroon), The authors thank Mr ALLARAMADJI Ndohortongar of N'Djaména hospital Le Bon Samaritain, for their assistance in this project. The authors also thank the Laboratory of the Medicinal Plants, Health and Galenic Formulation of the Department of Biological Sciences.

\section{Funding}

The authors declare that they have received no funding for the research reported.

\section{Availability of data and materials}

The datasets supporting the conclusions of this article are presented in this main paper. Plant materials used in this study have been identified at the Cameroon National Herbarium where voucher specimens are deposited.

\section{Authors' contributions}

NF designed the study and were involved in the drafting and correction of the manuscript, analysis and interpretation of data. DT supervised the study improved the mechanism study and corrected the manuscript. BC carried out the plant selection and collection and performed the experiments. TE provided technical assistance in carrying out biochemical assays, contributed some reagents. KADR helped in recording of diuretic parameters and provided technical assistance. All the authors read the manuscript, critically revised it for important intellectual content and approved the final version of the manuscript

\section{Competing interests}

The authors declare that they have no competing interests.

\section{Consent for publication}

Not applicable in this section.

\section{Ethic approval and consent to participate}

Ethics Committee of the Department of Biological Science of the University of Ngaoundéré (ECDBSUN 15/01/2015/UN/FS/DSB)

\section{Author details}

'Department of Biological Sciences, Faculty of Sciences, University of Ngaoundéré, P.O. Box 454, Ngaoundéré, Cameroon. ²Department of Chemistry, Faculty of Science, University of Ngaoundéré, P.O. Box 454, Ngaoundéré, Cameroon. ${ }^{3}$ Department of Animal Biology and Physiology, Faculty of Science, University of Yaoundé 1, P.O. Box 812, Yaoundé, Cameroon.

Received: 28 April 2016 Accepted: 25 October 2016 Published online: 13 December 2016

\section{References}

1. Fonarow GC, Smith EE, Reeves MJ, Pan W, Olson D, Hernandez AF, et al. Hospital-level variation in mortality and rehospitalization for medicare beneficiaries with acute ischemic stroke. Stroke. 2011:42:159-66.

2. Barakat $L A$, Mahmoud $\mathrm{RH}$. The antiatherogenic, renal protective and immunomodulatory effects of purslane, pumpkin and flax seeds on hypercholesterolemic rats. N Am J Med Sci. 2011;3:411-7.

3. Ashu Agbor M, Naidoo S. Ethnomedicinal plants used by traditional healers to treat oral health problems in Cameroon. Evidence-based complementary and alternative medicine, Hindawi Publishing Corporation. 2015. Article ID 649832, 10 pages. http://dx.doi.org/10.1155/2015/649832.
4. Martin N, Pantoja C, Chiang L, Bardisa L, Araya C, Roman R. Hemodynamic effects of a boiling water dialysate of maize silk in normotensive anaesthetised dogs. J Ethnopharmacol. 1991;31:259-62.

5. Caceres A, Giron LM, Martınez AM. Diuretic activity of plants used for the treatment of urinary ailments in Guatemala. J Ethnopharmacol. 1987;19(2):233-45

6. Yeo SK, Ooi LG, Lim TJ, Liong MT. Antihypertensive properties of plantbased prebiotics. Int J Mol Sci. 2009;10(8):3517-30.

7. Aiyelaagbe $\mathrm{OO}$, Osamudiamen PM. Phytochemical Screening for Active Compounds in Mangifera indica Leaves from Ibadan, Oyo State. Plant Sci Res. 2009;2(1):11-3.

8. Letouzey R. Etude Phytogeographique du Cameroun. Paris: Lechevalier; 1968. p. 511.

9. Hamawa Y, Mapongmetsem PM, Nkongmeneck BA, Dongock ND. Altitudinal distribution of Vepris heterophylla (Engl.) R. Let. (Rutaceae): A multifunctional plant of the Sudano-Sahelian zone of Cameroon. Int J Bot. 2010;6:243-50.

10. Moulis C, Fonraste I, Keita A, Bessire JM. Composition of leaf essential oil from Vepris heterophylla R. Let. Flavour Fragr J. 1994;9:35-7.

11. Keita A, Ouattara S. A propos d'une espece vegetale medicinale en voie de disparition au Mali: le Kinkeliba de Kita. Pharm Med Trad Afr. 1995;19:39-42.

12. Ntchapda F, Talla E, Obono BC, Agoni V, Moccia F, Tanzi F, Mbafor TJ, Dimo T. Endothelium-dependent vasorelaxant effects of the methanol stem bark extract of Vepris heterophylla (Engl.) R. Let. (Rutaceae) on rat aorta. Acad J Med Plants. 2013;1(3):041-8.

13. Ntchapda F, Talla E, Obono BC, Moccia F, Tanzi F, Mbafor Tanyi J, Dimo T. Vasorelaxant effects of Vepris heterophylla (Engl.) R. Let. (Rutaceae) methanol leaf extract on rat thoracic aortic strips. DOI. RA-2013-JPCOL. J Phytother Pharmacol. 2013;2(1):14-22.

14. Ntchapda F, Talla E, Obono BC, Dabolé B, Guido D, Moccia F, Tanzi F, Mbafor Tanyi J, Dimo T. Nitric oxide-dependent vasodilation and intracellular $\mathrm{Ca}^{2+}$ concentration increase induced by 6,8-dihydroxy-4methoxyflavone in rat aorta. J Pharmacognosy Phytother. 2013;5(7):114-9.

15. Ntchapda F, Talla E, Obono BC, Dabolé B, Guido D, Rappa A, Moccia F, Tanzi F, Mbafor Tanyi J, Dimo T. Intracellular $\mathrm{Ca}^{2+}$ signalling concentration increase induced by 3-16, 23, 29-tetrahydroxyoleane-12-ene (THO) on rat aorta endothelial cells. J Anim Plant Sci. 2013:17(2):2540-51.

16. Ntchapda F, Djedouboum A, Kom B, Nana P, Bonabe C, Maguirgue K, Talla E, Dimo T. Diuretic Activity of the Aqueous Extract Leaves of Ficus glumosa Del. (Moraceae) in Rats. Sci World J. 2014;ID: 693803; http://dx.doi.org/10. 1155/2014/6938803

17. Ntchapda F, Dimo T, Barama J, Kemeta Azambou DR, Seke Etet PF. Diuretic and antioxidant activities of the aqueous extract of leaves of Cassia occidentalis (Linn.) in rats. Asian Pac J Trop Med. 2015:8(9):685-93.

18. Trease GE, Evans MC. Textbook of Pharmacognosy. London: Bailliere, Tindall; 1978.

19. Edeoga HO. Phytochemical constituent of some nigerian medicinal plants Afr J Biotechnol. 2005:4(7):685-8.

20. Heslem E. Plant polyphenol vegetal tannin relisted-chemistry and pharmacology of natural products. Cambridge University Press; London, 1989. p. 169.

21. Denwick PM. Natural products a biosynthetic approach. 2nd ed. England: John Wiley and Sons Ltd; 2002. p. 241-3.

22. Murugesan T, Manikandan L, Suresh KB, Pal M, Saha BP. Evaluation of Diuretic potential of jussiaea suffruticosa Linn. Extract in rats. Indian J Pharm Sci. 2000;62(2):150-1.

23. Gupta RK, Kesari AN, Diwakar S, Tyagi A, Tandon V, Chandra R, Watal G. In vivo evaluation of anti-oxidant and anti-lipidimic potential of Annona squamosa aqueous extract in Type 2 diabetic models. J Ethnopharmacol. 2008;118:21-5.

24. Ratnasooriya WD, Pieris KP, Samaratunga U, Jayakody JR. Diuretic activity of Spilanthes acmella flowers in rats. J Ethnopharmacol. 2004;91:317-20.

25. Vargas Solis R, Perez Gutierrez RM. Diuretic and urolithiatic activities of the aqueous extract of the fruit of Randia echinocarpa on rats. J Ethnopharmacol. 2002:83:145-7.

26. Horistberger JD, Giebisch G. Potassium-sparing diuretics. Ren Physiol. 1987; 10:198-200.

27. Maghrani M, Zeggwagh NA, Haloui M, Eddouks M. Acute diuretic effect of aqueous extract of Retama raetam in normal rats. J Ethnopharmacol. 2005;99:31-5.

28. Shao F, Chen HJ, Liu RH, Hou YC, Ren G, Huang HL, Tang FR. Effects of heishunpian total alkaloids on Cassia acutifolia induced mice diarrhea and contraction of isolated intestinal smooth muscle in rats. Zhong Yao Cai. 2013;36:1805-9. 
29. Arul A, Chogtu B, Bairy KL. Sudhakar, Mungli Prakash. Evaluation of diuretic activity of Amaranthus spinosus Linn. aqueous extract in Wistar rats. J Ethnopharmacol. 2012;140:424-7.

30. Osorio FV, Teitelbaum I. Mechanisms of defective hydroosmotic response in chronic renal failure. J Nephrol. 1997;10:232-7.

31. Freitas PCM, Pucci LL, Vieira MS, Lino RS, Oliveira CMA, Cunha LC, Paula JR, Valadares MC. Diuretic activity and acute oral toxicity of Palicourea coriacea (Cham.) K Schum. J Ethnopharmacol. 2011;134:501-3.

32. Ying-Yong Z, Ya-Long F, Xiao D, Zhi-Hui X, Xian-Long C, Feng W. Diuretic activity of the ethanol and aqueous extracts of the surface layer of Poria cocos in rat. J Ethnopharmacol Commun. 2012;144(2012):775-8.

33. Zhao YY, Xie RM, Chao X, Zhang Y, Lin RC, Sun WJ. Bioactivity- directed isolation, identification of diuretic compounds from Polyporus umbellatus. J Ethnopharmacol. 2009;126:184-7.

34. Jouad H, Lacaille-Dubois MA, Eddouks M. Chronic diuretic effect of the water extract of Spergularia purpurea in normal rats. J Ethnopharmacol. 2001:75:219-23.

Submit your next manuscript to BioMed Central and we will help you at every step:

- We accept pre-submission inquiries

- Our selector tool helps you to find the most relevant journal

- We provide round the clock customer support

- Convenient online submission

- Thorough peer review

- Inclusion in PubMed and all major indexing services

- Maximum visibility for your research

Submit your manuscript at www.biomedcentral.com/submit 